\title{
Gastric Cancer pNX TNM Finding v8
}

National Cancer Institute

\section{Source}

National Cancer Institute. Gastric Cancer pNX TNM Finding v8. NCI Thesaurus. Code C133618.

Gastric cancer in which the regional lymph node(s) cannot be assessed. (from AJCC 8th Ed.) 